\title{
Adult Haematooncology Cases: A Six Year Review At Lagos State University Teaching Hospital Ikeja
}

\author{
A Akinbami, M Dada, A Dosunmu, M Balogun
}

\begin{abstract}
Citation
A Akinbami, M Dada, A Dosunmu, M Balogun. Adult Haematooncology Cases: A Six Year Review At Lagos State University Teaching Hospital Ikeja. The Internet Journal of Dental Science. 2008 Volume 7 Number 2.
\end{abstract}

DOI: $\underline{10.5580 / 13 \mathrm{f} 2}$

Abstract

BACKGROUND: Heamato-oncology is a malignant neoplasia of the blood and blood forming organs, such as the bone marrow, blood cells, and lymphoid tissues. The overall goal of the study was to determine the frequency distribution of Hematooncological cases seen at the Lagos State University Teaching Hospital IkejaMATERIALS \& METHODS: This was a retrospective review of Hemato-oncological cases seen at the Lagos State University Teaching Hospital Ikeja over a period of six years from 1st January 2001 to 31st December 2006, who presented at Lagos State University Teaching Hospital Ikeja. All case notes of patients seen at the clinic and those admitted through the medical emergency were retrieved and relevant data were extracted to a standard. form.RESULTS: A total of eighty-one case notes were seen consisting of $23\{28 \%\}$ each. of Chronic Myeloid Leukemia and Chronic Lymphocytic Leukemia.. Twelve cases $\{14.6 \%\}$ of Non-Hodgkin's lymphoma, ten cases $\{12.2 \%\}$ of Multiple Myeloma, seven $\{8.5 \%$ of Acute Lymphoblastic Leukemia, five $\{6.1 \%$ of Hodgkin's lymphoma, and one $\{1.2 \%\}$ of Acute Myeloid Leukemia.CONCLUSION: Acute Lymphoblastic Leukemia was noted to be commoner than Acute Myelogenous Leukemia in adult contrary to Literature findings, Chronic Lymphocytic leukemia and Multiple Myeloma were diagnosed mainly in the elderly in keeping with other previous studies and Non-Hodgkin's lymphoma is also commoner than Hodgkin's lymphoma in this environment.

\section{INTRODUCTION}

Heamato-oncology could be broadly classified into four groups, namely; Acute leukemia \{consisting of Acute Lymphoblastic Leukemia, Acute Myeloid Leukemia and Myelodysplastic syndrome $\}$. Myeloproliferative disorders \{consisting of Chronic Myeloid Leukemia, Polycythaemia vera, Myelofibrosis and, Essential thrombocythaemia.\} Lymphoproliferative disorders \{consisting of non-Hodgkin's Lymphoma, Hodgkin's Lymphoma, Chronic Lymphocytic Leukemia, and Hairy cell leukemia.\} and Plasma cell dyscrasias such as Multiple Myeloma, Monoclonal gamopathy of undetermined significance, Smouldering Multiple Myeloma, Waldestrom Macroglobulinemia and Heavy chain disease.

Heamato-oncology affects all ages and demonstrates biological, morphologic and clinical heterogenity ${ }_{1}$ Williams .C. $\mathrm{K}_{2}$ in 1985 found deviant biology of some haemopoetic malignancies in the study of clinical and epidemiological features of haemopoetic malignancies in Ibadan. Acute lymphoblastic leukemia (ALL) has its greatest incidence less than ten years of age and a modest secondary increase in frequency beginning at about fifty years of age ${ }_{3}$.ALL was not however observed after 40 years of age in Ibadan ${ }_{4}$ Acute myelogenous leukemia accounts for 15 to $20 \%$ of acute leukemia in children and $80 \%$ of acute leukemia in adults ${ }_{4}$. Chronic myeloid leukemia accounts for about $20 \%$ of all cases of leukemia ${ }_{5}$. Although, chronic myeloid leukemia occurs in all age groups, the median age of onset in Nigeria is 34.5 years compared to 50years reported in western population $_{6}$.In a similar study in 2006 a male: female ratio of 1.8:1 was observed in Nigeria by Boma P. O. et al with ages ranging from 12-74 (median 38 ) years ${ }_{7}$. Chronic Lymphocytic leukemia is a disease of the elderly with a median age of onset in Nigeria of 57.5 years and a male to female ratio of 2:1 ${ }_{6}$ CLL was also found in elderly patients (greater than 50 years) by Williams ${ }_{2}$. However, contrary to existing literature a female predominance in $\mathrm{M}$ : F ratio of 1:3 was observed by Omoti. ${ }_{8}$ (2007) at Benin City in 
Nigeria. CLL incidence was also found to be $36.4 \%$ of total leukemia in the same study, with median age being 56 years amongst a peak age group of 51-60 years, whilst $15 \%$ were below 40 years

The mean age at diagnosis of Non-Hodgkin's lymphoma in the U.S is $42 \pm 3$ years and the median age is $62 \pm 3$ years ${ }_{9}$ .The mean age in Nigeria is $32.3 \pm 16.3$ years while the median age is 29 years 10 . Hodgkin's disease has a bimodal age-incidence curve .Rates rise through early life, peaking in the third decade and declining until age 45 , after which the incidence increases steadily ${ }_{11}$. The median diagnosis of multiple myeloma, is 71 years. ${ }_{12}$ The male to female ratio is 1.4 to 1 . Myeloma accounts for $1 \%$ of all malignancies, $10 \%$ of all hematological malignancies in whites and $20 \%$ of all hematological malignances in African Americans ${ }_{13}$.

\section{MATERIALS AND METHOD}

This was a retrospective study of cases of adult hematological malignancies seen in the Department of Hematology and blood transfusion of Lagos State University Teaching Hospital Ikeja. All cases seen at the clinic and admitted through the emergency department from January 1 st 2001 to December $31{ }^{\text {st }} 2006$ were reviewed.

The following information were retrieved from the cases notes i.e. age, sex, occupation, religion, ethnic group, the presenting complaints, date of presentation, diagnosis and outcome. Diagnoses were mainly by morphology and histology. Non-availability of advanced hematological diagnostic techniques such as immunophenotyping and cytogenetics at the time patients were seen could limit accuracy of diagnosis.

The data was analyzed using the statistical package for social science version 13. Level of significance is taken at $\mathrm{P}<0.05$.

\section{RESULTS}

A total of eight-one (81) case notes were reviewed consisting of seven types of malignancies, namely, Chronic Lymphocytic Leukemia \{CLL\}, Chronic Granulocytic Leukemia, $\{\mathrm{CGL}\}$, non-Hodgkin's lymphoma, $\{$ NHL $\}$, Hodgkin's lymphoma $\{\mathrm{HL}\}$, Acute lymphoblastic leukemia $\{$ ALL, Acute myeloid leukemia $\{$ AML, Multiple Myeloma $\{\mathrm{MM}\}$. Out of the total case notes reviewed the highest number of $23\{28 \%\}$ each of Chronic Myeloid Leukemia and Chronic Lymphocytic Leukemia were observed. Twelve cases $\{14.6 \%\}$ of Non-Hodgkin's lymphoma, ten cases $\{12.2 \%$ of Multiple Myeloma, seven
$\{8.5 \%\}$ of Acute Lymphoblastic Leukemia, five $\{6.1 \%\}$ of Hodgkin's lymphoma, and one $\{1.2 \%\}$ of Acute Myeloid Leukemia. The frequency distribution is as shown in table $\mathrm{i}$.

The minimum age of presentation was 14 years and the maximum 85 years. . The mean and median ages per diagnosis were determined as shown in table i.The mean age of diagnosis of CLL was $61.91 \pm 10.53$ whilst it was $32 \pm 16$ for CGL (Table i). Comparing the age in groups with the diagnosis, CLL was seen more predominantly in the age group 61-70 years (8 cases), but CGL seen more in the age group 21-30 (7 cases). $\mathrm{P}$ value $=0.001$ table ii. Sex distribution showed male preponderance except for multiple myeloma in which equal sex distribution was observed. table i.

The mean age at diagnosis of non-Hodgkin's lymphoma was $38.67 \pm 14.82$ and the median age $34.50 \pm 14.82$ years. The mean and median ages of Hodgkin's lymphoma were 31.60 \pm 20.51 years and $22 \pm 20.51$ years respectively (Table 1).The median/mean ages of Multiple Myeloma were $52 \pm$ 14.27 years and $37 \pm 14.27$ years respectively. The result also showed the mean age of presentation of Acute Lymphoblastic Leukemia as $24.29 \pm 15.25$ years and the median age $19 \pm 15.25$ years. Two cases of ALL each were found in the age groups $41-50$ and 51-60 years (Table ii).

\section{Figure 1}

Table 1: The Age and Sex distribution of patients

\begin{tabular}{|c|c|c|c|c|c|c|c|c|c|}
\hline Diagnosis & Frequency & Percent & $\begin{array}{l}\text { Sex } \\
\text { Male }\end{array}$ & & $\begin{array}{l}\text { Mean } \\
\text { Age in } \\
\text { Years }\end{array}$ & $\begin{array}{l}\text { Median } \\
\text { Age in } \\
\text { Years }\end{array}$ & $\begin{array}{l}\text { Minim } \\
\text { um } \\
\text { Age in } \\
\text { Years }\end{array}$ & $\begin{array}{l}\text { Maxi } \\
\text { mum } \\
\text { Age in } \\
\text { Years }\end{array}$ & $\begin{array}{l}\text { Std } \\
\text { deviaton }\end{array}$ \\
\hline CLL & 23 & 28 & 13 & 10 & 61.91 & 64 & 37 & 77 & 10.53 \\
\hline $\mathrm{COL}$ & 23 & 28 & 12 & 11 & 34.43 & 32 & 14 & 85 & 16 \\
\hline NHL & 12 & 14.6 & 8 & 4 & 38.67 & 34.50 & 21 & 70 & 14.82 \\
\hline $\mathrm{HL}$ & 5 & 6.1 & 4 & 1 & 31.60 & 22 & 17 & 67 & 20.51 \\
\hline ALL & 7 & 8.5 & 4 & 3 & 24.29 & 19 & 14 & 48 & 15.25 \\
\hline AML & 1 & $1 . .2$ & 1 & 0 & - & - & - & $\cdot$ & - \\
\hline MM & 10 & 12.2 & 5 & 5 & 37 & 52 & 37 & 83 & 14.27 \\
\hline Total & 81 & 100 & 48 & 34 & 43.90 & 42 & 14 & 85 & 19.58 \\
\hline
\end{tabular}

\section{Figure 2}

Table 2: The Pattern of the age in group and diagnosis

\begin{tabular}{|l|l|l|l|l|l|l|l|}
\hline $\begin{array}{l}\text { Age in } \\
\text { Years }\end{array}$ & CLL & CGL & NHL & HL & ALL & AML & MM \\
\hline $10-20$ & 0 & 4 & 0 & 2 & 4 & - & 0 \\
\hline $21-30$ & 0 & 7 & 3 & 1 & 1 & 0 & 0 \\
\hline $31-40$ & 1 & 5 & 5 & 1 & 0 & 0 & 2 \\
\hline $41-50$ & 3 & 4 & 2 & 0 & 2 & 0 & 2 \\
\hline $51-60$ & 3 & 4 & 2 & 0 & 2 & 0 & 2 \\
\hline $61-70$ & 8 & 1 & 2 & 1 & 0 & 0 & 2 \\
\hline $71-80$ & 6 & 0 & 0 & 0 & 0 & 0 & 0 \\
\hline $81-90$ & 0 & 1 & 0 & 0 & 0 & 0 & 1 \\
\hline
\end{tabular}

\section{DISCUSSION}

CML and CLL appeared to be the commonest adult leukemia in Lagos. CML is common probably because it 
affects all age groups. It accounted for $28 \%$ of all Leukemia in Lagos, which is in keeping with the study of Lincet (1985). ${ }_{5}$ who observed CML accounting for $20 \%$ of all cases of Leukemia. CLL was also seen in almost all age group except those less than 30 years. However, this is an expected finding because CLL is a disease of the elderly.

A median age of $32 \pm 16$ of CML obtained in the present study is similar to 34.5 years obtained by Durosinmi. ${ }_{6}$ in a study conducted at Ife. ALL appeared to be commoner than AML in this study, the former accounting for $8.5 \%$ of all cases and the latter $1.2 \%$ of all cases of adult Hematooncology cases in Lagos. This is at variance with the study of Williams (1983). ${ }_{4}$ who found Acute Myelogenous Leukemia accounting for $80 \%$ of acute leukemia in adults. ALL was also not observed after 40 years by Oladipupo Williams . ${ }_{4}$ which is at variance with the present study in which two cases were seen each in the age groups 41-50 and 51-60 years.

The mean age of diagnosis of NHL obtained in the present study (38.67 \pm 14.82 years) is similar to $32.3 \pm 16.3$ years obtained in Nigerians by Ugboko et al . ${ }_{10}$ in 2004.This may be compared with $42 \pm 3$ years obtained in the U.S. 9

The 12.2\% Multiple Myeloma cases of all Heamato oncology cases in this study is comparable to $10 \%$ observed in whites but differs significantly from $20 \%$ obtained in African Americans $_{13}$. The median age of presentation of Multiple Myeloma was found to be $52 \pm 14.27$ years, this is at variance with 71 years obtained by Greenlee et $\mathrm{al}_{12}$

\section{CONCLUSION}

Acute Lymphoblastic Leukemia was noted to be commoner than Acute Myelogenous Leukemia in adult contrary to Literature findings, Chronic Lymphocytic leukemia and Multiple Myeloma were diagnosed mainly in the elderly in keeping with other previous studies. However, the median age of presentation of Multiple Myeloma in Lagos differs significantly from that in developed country. The median age of presentation of non-Hodgkin's lymphoma is similar to what is obtainable in the U.S. Non-Hodgkin's lymphoma is commoner than Hodgkin's lymphoma in this environment.

\section{References}

1. Lukes R.J,Collins R.D.Tumours of the haemopoetic system. Atlas of tumor Pathology,2nd series Fascicle 28, Washington,D.C:Armed Forces Institute of Pathology, 1992:1-38.

2. Williams.C.K Neoplastic diseases of the haemopoetic system in Ibadan: preliminary report of a prospective study Afr.J.Med Sci.1985, Mar-Jun;14 (1-2):89-94.

3. Cutler S.J. Axtel L, Heis H: Ten Thousand cases of Leukemia.1940-62.JNCI 1964.993.

4. Williams O. C.K, Bamgboye E.A. Estimation of incidence of human leukemia subtypes in an urban African population.Oncology.1983; 40 (6):381-6.

5. Lincet M.S: The Leukemias: Epidemiological Aspect.8th edition, Oxford University Press, New York,1985:20

6. Durosinmi.M.A. A design Handbook of Hemato-oncolgy Chemotherapy for Medical Students \& Doctors. Amkara and Allied services Ltd, 1998:28.

7. Boma .P.O. Durosinmi. M.A. Adediran.I.A. Akinola N.O, Salawu L. Clinical and prognostic features of Nigerians with chronic myeloid leukemia. Niger Postgrad Med J.2006 Mar;13 (1) ;47-52

8. Omoti C.E. Awodu .O.A, Bazuaye G.N. Chronic lymphoid leukaemia: clinico-haematological correlation and outcome in a single institution in Niger Delta region of Nigeria. Int J Lab Hematol.2007 Dec;29 (6): 426-32 9. John .P. Greer, John. Foerster, Wintrobe's Clinical Hematology 11th edition, Lippinncot Williams and Wilkin's 2004 Vol 2:2366

10. Ugboko V,I. Oginni F.O, Adelusola K.A, Durosinmi M.A. Orofacial non-Hodgkin's lymphoma in Nigerians J oral Maxillofac. Surg. 2004 Nov; 62 (11): 1347-50.

11. Grufferman S. Duong F, Cole P, Occupation and Hodgkin's disease. J.Natl Cancer Inst 57;1193,1976.

12. Greenlee RT, Hill-Harmon MB, Murray T, et al Cancer Statistics,2001.C.A.Cancer J.Clin 2001;51:15-36.

13. Howe H.L, Wings.P.A. Thun M J, et al .Annual report to the nation on the status of cancer (1973 through 1988),featuring cancers with recent increasing trends.J.Natl Cancer Inst 2001;93:824-842. 


\title{
Author Information
}

A.A. Akinbami

Department of Hematology and Blood Transfusion, Lagos State University, College of Medicine

\section{M.O. Dada}

Department of Hematology and Blood Transfusion, Lagos State University, College of Medicine

\author{
A.O. Dosunmu \\ Department of Hematology and Blood Transfusion, Lagos State University, College of Medicine \\ M.T. Balogun \\ Department of Hematology and Blood Transfusion, Lagos State University, College of Medicine
}

